\title{
The Reception of William Paley's Natural Theology in the University of Cambridge
}

\begin{abstract}
Aileen Fyfe
In order to pass the BA examination, it was, also, necessary to get up Paley's Evidences of Christianity, and his Moral Philosophy. This was done in a thorough manner, and I am convinced that I could have written out the whole of the Evidences with perfect correctness, but not of course in the clear language of Paley. The logic of this book and as I may add of his Natural Theology gave me as much delight as did Euclid. The careful study of these works, without attempting to learn any part by rote, was the only part of the Academical Course which, as I then felt and as I still believe, was of the least use to me in the education of my mind.
\end{abstract}

Charles Darwin. ${ }^{1}$

One of the books Darwin read at Cambridge was William Paley's Natural Theology (1802). Many scholars have assumed that this was a set text at the University in the early nineteenth century. ${ }^{2}$ However, a study of the examination papers of the University, and contemporary memoirs, autobiographies and correspondence, reveals no evidence that this was so, though it did appear in some of the College examinations. ${ }^{3}$ This contrasts with other books by Paley which did appear for many years on both University and College examinations. This paper uses the misapprehension about Paley's text as a starting point to investigate the role of natural theology in a Cambridge education in the first three decades of the nineteenth century.

Theology proves to have been a relatively minor part of the formal curriculum, and natural theology played only a small role within that. The political and religious context suggests that natural theology was less emphasised because of its associations with deism and radicalism. However, I suggest that this is an absence only from formal spheres of education. 
There was great interest in the natural sciences in Cambridge, and many of the professors undoubtedly saw natural theology as the framework in which they pursued their science. Despite being 'voluntary,' it was through the lectures, and the infectious enthusiasm of the natural sciences professors that natural theology played a far more important role than the analysis of examinations suggests. ${ }^{4}$

\section{Paley at Cambridge}

William Paley (1743-1805) wrote three books which he believed formed a system containing 'the evidences of Natural Religion, the evidences of Revealed Religion, and an account of the duties that result from both. ${ }^{5}$ These were, respectively, Natural Theology, A View of the Evidences of Christianity (1794), and Principles of Moral and Political Philosophy (1785). All three works were acknowledged to be unoriginal, but were praised for their clarity and logical arguments.

Principles was based on the ethics lectures Paley gave to students at Christ's while a College tutor, and it immediately became a set text for moral philosophy at Cambridge, being disputed in the Senate House by 1790, and appearing on St. John's College examinations by 1791. ${ }^{6}$ It was his most famous (or notorious) book, not least because of its Christian utilitarianism, which was attacked by Adam Sedgwick in his Discourse on the Studies of the University. ${ }^{7}$ Principles finally disappeared from the Cambridge examinations in $1857 .^{8}$

'In the view of the divines of the first half of the nineteenth century, William Paley's happiest work was A View of the Evidences of Christianity.' ${ }^{9}$ Evidences aimed to logically demonstrate that the Scriptures containing the Christian Revelation were written by their attributed authors, that they were true, and that they were the word of God revealed to Man. It was extremely popular until the beginning of the present century, and remained on 
Cambridge examinations till 1920, when it was finally succeeded by more modern forms of biblical criticism. ${ }^{10}$ It is unclear when Evidences first became a set text, but it was firmly established by 1822, when it formed the subject matter one of the four papers on the new Previous examination for second-year students. ${ }^{11}$

Natural Theology; or evidences of the existence and attributes of the deity, collected from the appearances of nature was another great success. It had reached its tenth edition by the time Paley died, doing in three years what Principles and Evidences had taken a decade to do. ${ }^{12}$ There were at least six reviews of Natural Theology in 1802-3, and all were extremely favourable, praising the clarity of Paley's style and the logic of his reasoning. ${ }^{13}$ The reviewers agreed that Natural Theology would be important in the fight against atheism, with the Whig Edinburgh Review even claiming that Paley's was the first work constructed 'with any express reference to the objections of atheistical writers,' and praising him for 'the judicious disposition of his forces, and the skill and confidence with which he has extended his array to every point which atheism had affected to menace. ${ }^{14}$ Natural Theology was also welcomed as a devotional work for believers, with the Evangelical Magazine and the liberal Dissenting Monthly Review welcoming it for 'prov[ing] to the world that the advancement of true philosophy seems to strengthen our belief in the Existence of God., ${ }^{15}$ Two reviewers mentioned its educational potential. The Dissenting Monthly Magazine 'recommend[ed] it as a text-book to those who superintend the religious instruction of the young, the ignorant, and the poor, ${ }^{16}$ while Edward Pearson, later Master of Sidney Sussex College, Cambridge, suggested in the Anglican Churchman's Magazine that it was a work 'to which our academic youth may be referred with so much safety and advantage. ${ }^{17}$

The few specific criticisms of Natural Theology are important, because they help to explain the reception in Cambridge. The Evangelical reviewers were concerned about the apparent self-sufficiency of natural theology in Paley's account. The Evangelical Magazine worried 
lest readers 'dangerously conclude that no other religion [i.e. Scripture] is necessary to their eternal salvation. ${ }^{18}$ Both reviewers pointed out that natural theology could be only a confirmation of Revelation, and, while praising Paley's attacks on atheism, were clearly worried about the potential for abuse by deists. The point was made very clearly by William Wilberforce's comment in the Christian Observer that some of Paley's assertions were 'both untenable and unsafe... We are the more suspicious of the sentiment... because we recollect that it was made the grounds of the theological system of [the noted deist and radical] Thomas Paine. ${ }^{19}$ Thus, the Evangelicals associated Paley's work with deism, which was not only not Christian, but had dangerous associations with radicalism after the French Revolution. Paley himself was certainly not a deist, and had devoted an entire book (Evidences) to revealed religion, but it is significant that Natural Theology considered on its own could be taken as close to deism.

Despite these Evangelical criticisms, the reviews were generally favourable, and this was reflected in sales. It went through fifteen editions in as many years, and while the print runs are not known, this suggests sales of around 15,000 copies. ${ }^{20}$ This is exceptionally good for a gentlemanly octavo. There are some practical reasons for its success. It was relatively short, and as the reviewers agreed, extremely well-written. Paley made effective use of analogies to explain his points, and made a conscious attempt to limit himself to examples which would be easily comprehensible without the need for diagrams or technical language. ${ }^{21}$ That these features were appreciated by the public is illustrated by the anatomist Charles Bell's belief that 'their simplicity and almost childishness have been the sources of popularity of that book. $^{, 22}$ Paley was especially good at recognising potential weaknesses in his own arguments, which he would then answer before his opponents had the chance to criticize them. Finally, through his writing, Paley conveyed an unlimited enthusiasm and awe for his subject, which reflected his own 'intense appreciation of God's creation. ${ }^{23}$ 
Natural Theology is frequently associated with the paradigm that was overthrown by Charles Darwin's On the Origin of Species (1859). This is rather simplistic since natural theology did not suddenly end in 1859 , and natural theologies changed between 1802 and 1859 so that natural theology immediately prior to the Origin did not have as much in common with that of Paley as is often thought. ${ }^{24}$ Yet the fact that Paley is so often linked with the preDarwinian state of affairs is further evidence for the respect and longevity which his work enjoyed. Even those who no longer accepted his argument exactly as he expressed it could still respect and admire his work as one of the best of the genre. Darwin himself was of this opinion. $^{25}$

Since Paley's Evidences and Principles were both used to teach their subjects at Cambridge, we might expect that his Natural Theology would also be taken up as a text. Confusion has arisen among scholars due to references to 'Paley' on the examinations, without details of which of Paley's works, and false conclusions have thus been reached about the examined texts. An inspection of the examination papers reveals that 'Paley' could mean either Principles, or Evidences, or both, depending upon the period and the level of examination in question. That 'evidences' was also the subtitle of Natural Theology has furthered the confusion. However, as I will show, the latter work made no recorded appearance on the University examinations before 1833. The situation in the Colleges, and outside the degree examinations was slightly different.

At the time of the publication of Natural Theology, Oxford and Cambridge were the only universities in England. They were bound up with tradition, closely associated with the Established Church of England, and felt by many to be in need of reform. The Oxford curriculum was based almost entirely upon the classics, with a small amount of theology. Cambridge men were extremely proud of what they felt to be their superior curriculum, boasting the three areas of natural philosophy, moral philosophy, and the classics. ${ }^{26} \mathrm{~A}$ 
contributor to the Monthly Magazine called it a 'very liberal system of education..., exquisitely adapted to rouse genius into energy and sluggishness into action. ${ }^{27}$

Such a proud claim masked the fact that in reality the most important parts of the examination for the degree of BA at Cambridge were mathematics and natural philosophy. 'Mathematics' meant Euclidean geometry, trigonometry, some calculus, and a little algebra. 'Natural philosophy' tended to be what is now termed 'applied mathematics,' in which Newtonian mechanics and astronomy featured strongly. These were the subjects which were emphasised in the University examinations. The moral philosophy and classics tended to be taught in the Colleges, and comprised only a small part of the degree examination. This meant that the only incentives for studying them were a desire for self-improvement, or to win one of the prizes which were often awarded in classics, and occasionally in moral philosophy, as well as in mathematics.

During the course of the nineteenth century, many reforms were made to the University's teaching and examination system. By 1877, Christopher Wordsworth was able to write that: 'No one who has any experience of the working and life of Cambridge can be ignorant how completely we have been removed from Cambridge of half a century ago, or that we have lost almost the last glimpse of what our University, even forty years since, was like. ${ }^{28}$ It is in this context that we must consider the reception of Natural Theology. An old university which had been committed to a rational education based on mathematics was undergoing reform. Its examination and teaching systems were being improved, its curricula broadened, and eventually its links with the Established Church were to be altered. ${ }^{29}$

There were three different systems of teaching within the University. At the University level, professors were appointed by the University, and degree examinations were set and marked by University officials. Secondly, in the Colleges, there were lecturers and tutors, and 
sometimes annual examinations and scholarship or prize examinations. The third system was not officially part of the University system, and hence was often looked on with disapproval. A number of private tutors provided one-to-one tuition for students in order to get them through the University examinations. They were extremely important to many students since the teaching of the Colleges, and of the University professors, did not necessarily fit into the University examination scheme, yet it seems unlikely that we can look to them for the study of natural theology. They followed the curriculum of the University, as expressed in its examinations, and, despite the claims that both revealed and natural theology featured on the examinations, very little theology was actually examined, and it was almost all revealed theology.

In addition to the examination papers of the University, I have studied College examination papers, and searched the memoirs and letters of some of the Cambridge undergraduates, fellows and professors of the period in an effort to determine Natural Theology's unofficial reception. ${ }^{30}$ There are disappointingly few references to natural theology in any of this material, which makes it difficult to draw firm conclusions. This lack of evidence raises questions both about Natural Theology's suitability as a textbook, and about Cambridge's need for such a textbook. They also illustrate the difficulty of tracing tacit assumptions and knowledge. However, I have been able to find some evidence for the use of Natural Theology.

We are all familiar with the ways in which natural theology and the natural sciences can be related. ${ }^{31}$ Yet, in the context of a Cambridge examination, natural theology would have been part of a divinity paper. It is therefore important to consider natural theology's relations with theology, particularly with respect to Revelation. Contemporary trends in theology may have been reflected in the use made of natural theology by men of science. Natural theology could have been combined with Revelation in one of two ways: as a rational foundation upon which 
to build Christianity, which would later be extended by the Scriptures; or as a way to rebuff attacks on a Christianity which had been pre-established by Revelation. Paley probably saw his text in the former light, which was typically Latitudinarian. However, the fact that the contemporary reviewers did not mention a foundational role, but praised the book especially for defending Christianity from atheism suggests that at least some readers interpreted the work in a different way. After the French Revolution, a foundational natural theology appeared to be very close to deism, which was itself now linked to radicalism and revolution. For British, Christian reviewers, therefore, natural theology had to be given a safer role as a defence against atheism, including the French atheism feared by Wilberforce. ${ }^{32}$ With one exception, the evidence, and lack of evidence, that I have found for Natural Theology in Cambridge supports this interpretation of the reviewers' reactions.

\section{University Examinations}

At the beginning of the nineteenth century, the examinations taken in the Senate House in the tenth term of residence lasted for four days. ${ }^{33}$ The first two days were mathematical, while the third was devoted to logic and moral philosophy. On the last day, the examiners asked whatever questions they felt were needed to separate out the candidates - usually this meant mathematical questions. The third day had been introduced in 1779 to place more emphasis upon 'Natural Religion, Moral Philosophy, and Locke,' subjects whose examination had previously been 'very superficial. ${ }^{34}$ This may have been an attempt to redress the imbalance which had developed between mathematics and metaphysical studies, which Henry Sidgwick attributed to the greater interest in Newtonian natural philosophy, and the fact that its questions were more suited to written examinations. ${ }^{35}$ Gascoigne has suggested that, by the late eighteenth century, the falling numbers of candidates continuing to the BD degree made the lack of theology in the BA a more pressing problem than it had previously been. ${ }^{36}$ 
The Cambridge University Calendars referred to the subject matter of the third day as 'Logic, Moral Philosophy and points relative to Natural and Revealed Religion etc.' ${ }^{37}$ The Calendar began to print the examination papers, and a selection of the questions which had been delivered viva voce, in 1802. Unfortunately, in 1803, it stopped printing those from the moral philosophy day, concentrating instead on the mathematical questions. Investigating the examined material of non-mathematical subjects is therefore difficult.

The printed examination papers are available from $1824 .^{38}$ There are far more papers than in 1802, but the questions seem very similar. Papers were set on pure and applied mathematics, on Classical and Biblical texts, on Paley's Principles and Evidences, and on Locke's Essay on Human Understanding (1690). Generally, there was very little emphasis on divinity. That which did appear tended to be either New Testament texts to translate and answer contextual questions on, or questions on Paley's Evidences. It was rare for a question relating to natural theology to be asked, and I have been able to find only three:

'Prove that there is a God, independent of Revelation.' $(1802)^{39}$

'What proof does the light of nature afford us of the Divine benevolence?' (March, 1830) ${ }^{40}$

'Shew the absurdity of separating natural and revealed religion.' (January, 1831) $)^{41}$

While this is obviously a trivial sample, it is clear that the 1831 question stressed the importance of both natural and revealed theology, while the 1802 question accepted an independent natural theology.

Eighteenth-century Cambridge had been generally Latitudinarian in character, with the associated emphasis on toleration, and the similarities between denominations rather than their differences. Natural theology was a perfect example of what all believers had in common. It was also a way to rationalise religious belief and distance it from Enthusiasm, an 
undertaking which fitted well with the attempts of contemporary natural philosophy to provide a rational explanation of the world. Natural theology was important in ensuring that this rational 'scientific' world did not also become one detached from religion.

Deists based their religious belief on natural theology, but did not accept the Christian Revelation. After the French Revolution and the Terror, seen in Britain as having been caused by men of materialistic, irreligious ideas, deism became firmly associated with radicalism, which in turn was perceived as far more dangerous than before. Previously 'moderate' liberals distanced themselves from the more extreme radicals, and there was a general move towards conservatism and orthodoxy, in both politics and religion. Gascoigne has discussed some of the political reasons for this swing. ${ }^{42}$ The problem for natural theology was that it was what deists and Christians had in common.

This period also saw a rise in Christian Evangelicalism, which laid great emphasis on Revelation, and consequently relegated natural theology to its defence. Without a surrounding framework of Revelation, natural theology could be perceived as dangerously radical, or un-Christian. Paley placed his book in such a framework in his dedication, but it was not sufficient to convince the Evangelical reviewers. The conservative trend was apparent in Cambridge, and the Evangelical presence in parts of the University (especially at Queens' and Magdalene) was certainly growing, though I have been unable to find many examples of Cambridge Evangelicals commenting on natural theology. ${ }^{43}$ Charles Simeon, of King's, expressed the typical response: 'Investigate the works of creation; it cannot do any harm... but beware of feeding upon science, lest your souls be starved. ${ }^{44}$ The combined effect of conservatism and Evangelicalism would have reduced the emphasis on natural theology. Thus, by the $1820 \mathrm{~s}$, when natural theology was mentioned it tended to be in association with revealed theology. Evangelicals emphasised Revelation because of their belief in the importance of the atonement of Christ, but most other Christians were 
sufficiently aware of the dangers of radicalism to stress that natural theology was but one part of their religion. This is not to say that the men involved necessarily changed their personal beliefs, but rather that they were more circumspect about which parts of them they discussed in public.

\section{The University Professors}

In addition to setting degree examinations, the University appointed professors. There were twenty in 1802 , of whom almost half were in the natural sciences. ${ }^{45}$ There were also professors in divinity and related subjects, and in law and medicine. However, these professors had little role in the teaching of undergraduates. Firstly, many of them were not required to lecture, and even some of those who should have done so, did not. ${ }^{46}$ Secondly, many those who did lecture suffered from the disadvantage of a subject which was irrelevant to the examination system.

The keen young natural sciences professors of the 1820s, such as Adam Sedgwick, William Whewell, and John Stevens Henslow 'found their lecture rooms filled' on the strength of their lecturing ability and their subject matter. ${ }^{47}$ Henslow's great asset was said to be his ability to 'explain... in well-chosen language anything that his hearers might find difficult to understand. ${ }^{48}$ Becher implies that the popularity of the sciences in Cambridge in this period was due to their general appeal, their use of demonstrations and experiments, and the practical applications which were often stressed in the lectures. Both botany and geology were becoming popular among the students, with Henslow's botany lectures regularly achieving attendances of seventy between 1828-33, and mineralogy books being among those bought by students at Pembroke in $1820{ }^{49}$ A variety of informal clubs, societies, and soirees (such as those of Henslow) provided support and encouragement for such activities. However, the problem of the lack of formal recognition for the natural sciences remained, 
and it is clear from surviving attendance registers that the lecture rooms were not filled solely by undergraduates. ${ }^{50}$ Recent graduates, perhaps preparing for ordination or fellowship examinations, and occasionally fellows, often had the leisure as well as the interest to attend science lectures.

The natural sciences might be expected to play an important part in the reception of Natural Theology, since they provide much (but not necessarily all) of the subject matter for natural theology. Paley's book was full of examples taken from the natural sciences, though mostly from the realms of botany, zoology, and anatomy. Geology was not mentioned, illustrating how recent many of the geological discoveries were - by the 1820s, the Oxford geologist, William Buckland was arguing that geological evidence was an essential part of natural theology. ${ }^{51}$ Paley mentioned chemistry, but he felt that until it was better understood it could be of little use as a demonstration of mechanism. ${ }^{52}$ By the 1830 s chemical arguments were used to support natural theology. ${ }^{53}$ Astronomy received a chapter in Natural Theology, yet again Paley did not feel it to be the best method for demonstrating the existence of God, since, although it showed his magnificence, its mechanism was too little understood. ${ }^{54}$ Again, by the 1820 s and 1830 s, astronomy was being used in natural theological texts. ${ }^{55}$

This might suggest that Paley's Natural Theology would have been seen as out of date and old-fashioned very soon after its publication. After all, it was based on a series of sermons composed in the 1780 s or 1790 s. $^{56}$ But this does not seem to have been the case. Natural theology itself survived, through numerous adaptations which allowed it to accept a dynamic earth history with more than one creation. And although Paley's own version became obsolete, it was still regarded as the classic of the genre. Writers of new natural theologies were compared to Paley, often negatively, and themselves acknowledged that they had a great deal to live up to. ${ }^{57}$ One way around this was to 'extend' Paley by dealing with subjects not mentioned by him - such as chemistry, geology, astronomy and the physical sciences in 
general. This allowed the author to avoid direct comparison with Paley, while still producing a natural theology. Despite major changes in science, Paley's Natural Theology was able to retain its position of respect and authority.

By the 1820 s, the University professors were teaching a wide range of natural sciences, and it is clear that they regarded natural theology as essential to their studies. In 1833, Sedgwick wrote 'I cannot but urge on all those who are commencing their academic course, the habitual study of his [Paley's] delightful work on Natural Theology., ${ }^{58}$ Sedgwick was convinced that there are so many proofs of God's existence around us in the world (as shown especially by the natural sciences) that we cannot help but acknowledge God's existence, and he was in total agreement with Paley that 'contrivance proves design... This proof is so strong that it never has been and never can be gainsaid. ${ }^{59}$ Whewell, too, was convinced that 'a person who is unacquainted with science is blind to [the] many and wonderful views which... it gives him of the relations of ourselves and the world to the Deity, ${ }^{60}$ while Henslow considered the natural sciences to be one of the "the two witnesses to His infinite power, wisdom, and goodness. ${ }^{61}$ Men of science were not unaware of the danger that natural theology, and the sciences associated with it, could be associated with deism and radicalism. At Oxford, Buckland argued that: 'Nothing can be more unjust than the apprehension lest the study of nature, when rightly pursued... should in any way be destructive of the credibility of... the revelation of His will. ${ }^{62}$ Similarly, Cambridge men stressed the complementarity of natural and revealed religion. Sedgwick could not understand how 'any believer can deny the reality of natural religion when he reads those passages in the Bible where its power is so emphatically acknowledged,' and declared that 'the religion of nature and the religion of the Bible are therefore in beautiful accordance. ${ }^{93}$ Henslow advocated the natural sciences to 'assist... the inquiries of these learned men who devote themselves mainly to the study of the higher truths of Revelation,' and advised the young 'to take an equal interest in the works and the Word of God, as forming different parts only of the great volume put into our hands to 
read. ${ }^{64}$

There is no doubt that the Cambridge natural sciences professors saw natural theology as part of the rationale for their work. They felt that they were finding out about God by investigating His creation. Yet natural theology used in this way was not a subject for study or examination. However much these men may have encouraged their pupils to read Natural Theology or similar works, and to consider natural theology as an essential part of their education and understanding, this is not the type of appreciation and encouragement which tends to be recorded in detail. It is perhaps less surprising how little official recognition natural theology received from the University when it is considered in this light. Its association with the natural sciences (themselves extracurricular) was essential but implicit.

There seems to have been no University teaching in the classics (the Regius professor of Greek did not lecture), or in moral philosophy, allegedly two of the three components of Cambridge's 'liberal education'. The Norrisian Professor of Divinity was the only divinity professor who did lecture, though his course was aimed at candidates for ordination, who had to attend twenty-five of his lectures to obtain their testimonials. ${ }^{65}$ The lectures were therefore attended not by undergraduates, but by recent graduates, and may have been intended to supplement the small amount of theology taught in the BA course itself, by providing a complete education in the doctrines and creed of the Church of England. John Banks Hollingworth published the heads of his Norrisian lectures, with recommended reading, so it is possible to reconstruct his course. ${ }^{66}$ Hollingworth's lectures illustrate one of the two ways in which natural and revealed theology can be joined. In them, natural theology is used as a confirmation and defence of revealed theology.

Hollingworth chose to employ a system of divinity which 'explains and justifies Religious Belief as maintained by the Church of England,' rather than one which traces belief from its 
origin. ${ }^{67}$ His course of fifty lectures goes line by line through the creed, explaining it carefully with appropriate Biblical and exegetical references. Paley's Evidences are used in the discussion of miracles, and of Christ's intercession, his Principles in relation to the Sabbath, and his Horae Paulinae (1790) for the diffusion of Christianity. At the end of the course, consideration is given to the objections of Jews, Mahometans, deists, and atheists. A wide variety of authors are mentioned, but Paley's Natural Theology appears as one of the chief refutations of atheism. ${ }^{68}$ Unfortunately, since Hollingworth published only the heads of his lectures, we do not know what he actually said, but the way in which he used Natural Theology is clear: It was a defence for believers, not a rational foundation for their belief. This correlates with the points made previously about the influence of Evangelicalism and conservatism on natural theology. Placing natural theology prior to Revelation, as a foundation, would have been to accord it an extremely important position in religious belief, and to open the door to deism. A defence of Revelation was the only uncontroversial way of using natural theology in a theological education at this time.

It is interesting to find that Hollingworth did indeed use Natural Theology as a textbook for part of his course. This indicates that Paley's book was not itself unsuitable or inadequate as a textbook. I have already noted that the future Master of Sidney Sussex College considered Natural Theology to be a suitable work for academic youth, yet the lack of evidence for its use in this way might cast doubt on this. Unlike Principles, which was based on University lectures, Natural Theology was based on sermons, and might not be expected to convert well to an academic setting. However, like Paley's other works, it contained a clear and logical series of arguments, and a comprehensible set of examples to illustrate them. It was common for natural theologies to deal more with providing examples of mechanism and contrivance in nature, than to address the question of why contrivance is a proof of God's existence. ${ }^{69}$ In Paley, we find both examples and argument. Natural Theology's failure to become a Cambridge textbook was thus due to the lack of teaching of natural theology. This was an 
effect partly of the mathematical bias of the examinations, which reduced all theological (and classical) teaching, and partly of the conservative fear of over-emphasising natural theology, because of its deistic and radical associations.

\section{The Colleges}

Although the University professors are important for investigating the place of natural theology in the sciences, the Colleges might be expected to be more important for its role in theology. The Colleges paid more attention to undergraduate teaching in general, and though they were preparing students for mathematically biased examinations, they often retained a more liberal concept of education, concentrating on moral philosophy, divinity and classics more than their place in the examinations might seem to warrant.

College education took the form of lectures delivered by the fellows to small groups of students. The subject matter was in the hands of the College. Whewell expressed the problems the Colleges had in choosing their lecture subjects, when he noted that, formerly, college lectures were unrelated to University examinations, and were chosen by the College because they were felt to be 'valuable for their own sake, and proper parts of a liberal education.' He disapproved of the new tendency to 'conduct our education almost entirely by means of examinations, and to consider the lectures given in the Colleges as useful only in proportion as they prepare the student for success in the examinations. ${ }^{, 70}$

Undoubtedly, the reforms of the University examination system to reduce the mathematical bias assisted the College authorities. It seems, however, that most of them chose to stay as close to a liberal education as they could, without ignoring the fact that mathematics would be the most important part of the students' education. When Whewell was a Trinity undergraduate himself, in 1813, equal attention was devoted to mathematics and classics (an 
hour daily for each), and a smaller amount of time to divinity (an hour thrice weekly). ${ }^{71}$ It was also common for Colleges to establish prizes in classics, and occasionally moral philosophy (in addition to their mathematics prizes) to encourage the study of these subjects. $^{72}$ Yet even these attempts could do little against the fact that mathematics was needed for the degree, and that an Honours degree was often a prerequisite for competition for the prizes in other subjects.

St. John's was the first College to establish internal examinations, in 1765 , and they were emulated by Trinity in 1790 . By 1828 , all sixteen colleges held written examinations. ${ }^{73}$ College examinations provided a way for the tutors to ensure that their students were properly prepared for the Senate House examinations, and also to make certain that they actually studied during their first two years. The styles and standards of teaching, and of examinations, varied quite dramatically between the Colleges. At St. John's, it was essential to attend six College examinations before being permitted to take the Senate House examinations, a rule that was strictly enforced. ${ }^{74}$ The examination books record examples of men who were made to sit extra examinations, or repeat a year, as a result of poor performances. One unfortunate (or lazy) first year was ordered 'not [to] return to College till he shall have qualified himself to profit by the College Lectures,' after being found 'shamefully ignorant in all the subjects. ${ }^{, 75}$ In contrast, Jesuans had a far less rigorous regime. One fellow was worried that the candidates for the BA might not 'have had any Lectures on their Examination subjects. ${ }^{76} \mathrm{He}$ went on to offer to remedy the situation.

At all the Colleges, examination papers in mathematics, classics, and the New Testament were common. However, the variation in other papers was far greater. When the records began in 1828 , only Trinity and St. Peter's examined students on anything other than these staples - both asked questions on Paley's Evidences, while Trinity also set Principles and Locke's Essay, and St. Peter's set Bishop Tomline's Elements of Christian Theology ( $^{\text {nd }}$ ed. 
1799). ${ }^{77}$ By 1833, six colleges set Evidences, three Principles, and one Locke. Sidney Sussex was unique in setting Paley's Horae Paulinae along with his Evidences. Trinity's examinations were much broader than those of the other colleges, often including Aristotle's Ethics, and Joseph Butler's The Analogy of natural and revealed religion to the constitution and course of nature (1736), as well as the two Paleys and Locke. There is no record, however, of Natural Theology, and virtually no opportunity for it to appear, since the theology questions all deal with the Scriptures.

There is, however, a problem with studying the collections of examination papers in Cambridge University Library, and the Colleges. The collections in St. John's College were made by individual tutors, for their private use, and contain only selected papers, usually mathematical, and occasionally classical. The University Library collections are supposed to be more complete, but the papers for St. John's do not include all the papers which are recorded as having been set. The St. John's Examination Books record the set texts for each examination, and then list the examination results. ${ }^{78}$ From these lists of texts, it transpires that the University Library collections appear to be missing papers in moral philosophy. It is thus difficult to know with what certainty any conclusions can be reached about the status of moral philosophy in the Colleges.

The subjects for examination at St. John's reflect fairly closely the subjects examined by the University, as one would expect. However, the balance of subjects is more even - typically, students were examined on natural philosophy, moral philosophy or theology, and a classical text, as well as one of the books of the New Testament, and arithmetic and algebra. Mathematics was not as pre-eminent as on the University examinations, and the examiners often commended students for having achieved merit in the classics, despite being less able at mathematics. The moral philosophy, theology, and classical texts varied according to the level of students, and different texts were examined in June and December. Once they had 
sat six examinations, students would have answered questions on several Latin and Greek texts, all of Locke, and all the current texts for moral philosophy and theology. The set texts changed over time, and it is interesting to see how Paley's works gradually eased their way onto the examinations. By the 1790s, Paley's Principles had replaced Francis Hutcheson's A Short Introduction to Moral Philosophy (1753), while it was not until the 1820s that Evidences replaced Philip Doddridge's The Evidences of Christianity briefly stated (1770).

Most significantly, however, between 1829 and 1839, second year students were examined every December in Paley's Natural Theology. This is the only evidence I have been able to find of formal examination in Natural Theology in this period, although it is also mentioned as one of the set texts for a Trinity examination in $1842 .{ }^{79}$ It is therefore even more unfortunate that the St. John's examination papers in moral philosophy have not been kept, for we have no record of the type of questions that were asked.

However, there is one extremely interesting paper which survives. In Easter Term, 1832, King's College set a paper on their course of theological lectures. ${ }^{80}$ This examination paper provides an illustration of the second way in which natural and revealed theology may be combined. Since the examination has one question per lecture, it is possible to gain an impression of the content and order of the lectures. The course begins with natural theology to prove the existence and attributes of the Deity, proceeds through a discussion of these attributes to reach the doctrines of the Scriptures and of the Anglican Church, and ends with a critical assessment of the credibility of the Revelation. There is no explicit mention of Paley's Natural Theology, but there can be no doubt that it would have been an ideal text for the first part of the course. This was natural theology used in the way that Paley intended. It is, however, surprising, both because of the contemporary political and religious climate, and because it is not the way in which the University's Norrisian Professor used natural theology. As King's students did not have to sit University examinations before proceeding to the 
degree of BA, it is possible that their curriculum could afford to be less strictly tied to trends in the University, and it would be interesting to compare the examinations of King's and the other Colleges in this light.

$* * * * *$

From this analysis of the different levels of teaching and assessment in the University of Cambridge, we can see the difference between official University rubric, and the system that actually operated. Officially the curriculum was broad, as illustrated by the University Calendar descriptions of the degree system, and the range of subjects of the University professors. However, in effect, due to the narrowness of the examination system, it was limited to mathematics, with only a small measure of theology, classics and moral philosophy. The private tutors followed the emphases of the University. Only the Colleges made an attempt to maintain a broader education.

As far as natural theology is concerned, it rarely occurred on University or College examinations, and did not achieve equality with revealed theology. The surviving examples illustrate both the typically eighteenth-century use of natural theology as a foundation for Christianity (as at King's), and the more politically and religiously 'safe' use of natural theology as a defence of Revelation against atheism (as in the Norrisian lectures). The latter, along with the preponderance of revealed theology in the theological examinations, can be explained by the decreasing popularity of Latitudinarianism, the growing fear of deism, and the rise of Evangelicalism.

Natural theology played a different role in the natural sciences, but it is another remarkably poorly recorded role. The personal encouragement of the professors provided an informal education in natural theology for those students who were keen and interested, though the 
political context meant that they had to be careful to avoid the dangerous association with deism. The lack of written references reflects the fact that natural theology was accepted without question in the natural sciences community.

Thus we can see why natural theology did not have very much formal recognition in the mathematical University of Cambridge at a time when Evangelicalism was spreading, and deism was threatening. It could have been recognised only as a defence for theology or as an implicit background assumption for the natural sciences. This is a rather different picture from that of the Cambridge University which made Natural Theology a major set text. 
"Department of History and Philosophy of Science, University of Cambridge, CB2 3RH.

I am grateful to St. John's College, Cambridge, and Jesus College, Cambridge for permission to quote from archival material, and I thank the archivists at both Colleges for their assistance. I would also like to thank Jon Topham for all his constructive criticism and advice, and Jim Secord and Alistair Thomas for their helpful comments.

${ }^{1}$ F. Darwin, Life and Letters of Charles Darwin, 3rd edn, London, 1887, i, 47.

${ }^{2}$ E.g. M. M. Garland, Cambridge Before Darwin, Cambridge, 1980, 52-3; R. Young, Darwin's Metaphor, London, 1985, 30; B. Hilton, The Age of Atonement, Oxford, 1988, 171; J. Browne, Charles Darwin: Voyaging, London, 1995, 97; P. Broks, Media Science before the Great War, London, 1996, 55.

${ }^{3}$ There is no record of it at Christ's, where Darwin studied. It seems more likely that he read it after graduation, while preparing for ordination. See A. Desmond and J. Moore, Darwin, London, 1991, 90. ${ }^{4}$ H. W. Becher, 'Voluntary Science in Nineteenth Century Cambridge', BJHS (1986), 19, 57-87. ${ }^{5}$ W. Paley, Natural Theology, [1802], Edinburgh, 1818, dedication.

${ }^{6}$ B. R. Schneider, Wordsworth's Cambridge Education, Cambridge, 1957, 181; Examination Books 1766-1843, St. John's College Archives, Cambridge [SJA]; Edmund Paley's memoir of his father, attached to The Works of William Paley, DD (ed. E. Paley), 7 vols., London, 1825, i, 129 gives 1785-6 as the date of Principles's adoption at Cambridge; M. L. Clarke, Paley: Evidences for the Man, London, 1974, 126-7, gives it as 1787.

${ }^{7}$ A. Sedgwick, A Discourse on the Studies of the University, [1833], (ed. E. Ashby and M. Anderson), Leicester, 1969, 49 ff.

${ }^{8}$ Clarke, op. cit. (6), 128.

${ }^{9}$ D. Yule, 'The Impact of Science on British Religious Thought in the Second Quarter of the Nineteenth Century', PhD thesis, Cambridge University, 1976, BLDSC D17081/76, 37.

${ }^{10}$ The last question on the Previous examination in 1920 was "In view of the interests of the Christian religion, is it wise or unwise to discontinue the paper on Paley's Evidences in the Previous Examination?" Cambridge University Examination Papers 1824-, [CUEP], in Cambridge University 
Library [CUL], 9 December 1920.

${ }^{11}$ Cambridge University Calendar, Cambridge, 1796-1833, [CUC], 1822; CUEP, 1824; D. L. LeMahieu, The Mind of William Paley, London, 1976, 162, claims that Evidences was on reading lists before 1822, but it did not appear in CUC, 1802, and did not reach St. John's College till 1823, Examination Books, SJA.

${ }^{12}$ Principles, 1 st ed. 1785, 10th ed. 1794. Evidences, 1st ed. 1794, 10th ed. 1804. Natural Theology, 1st ed. 1802, 10th ed. 1805. The last edition of Natural Theology that I have been able to trace was published by the SPCK in 1902.

${ }^{13}$ [Anon.], 'Dr. Paley's Natural Theology,' Edinburgh Review (1802), 1, 287-305; [Anon.], 'Review of Paley's Natural Theology,' Evangelical Magazine (1803), 11, 494-5; [Anon.], 'Retrospect of Domestic Literature - Theology,' The Monthly Magazine (1803), 15, 614; [Anon.], 'Paley's Natural Theology,' The Monthly Review (1803), 42, 262-73; E. Pearson, 'Letter to Dr. Paley,' The Churchman's Magazine (1802), 3, 293-5; [W. Wilberforce], 'Review of Paley's Natural Theology', Christian Observer (1803), 2, 162-6, 240-4, 369-74. For the attribution of authorship to Wilberforce, see B. Hilton, op. cit. (2), 178; J. R. Topham 'Evangelicals, science, and natural theology in early nineteenth century Britain: Thomas Chalmers and the Evidence controversy,' forthcoming, fn. 23.

${ }^{14}$ Edinburgh Review, op. cit. (13), 291, 304.

${ }^{15}$ Monthly Review, op. cit. (13), 262-3; also Evangelical Magazine, op. cit. (13), 494.

${ }^{16}$ Monthly Magazine, op. cit. (13), 614.

${ }^{17}$ Pearson, op. cit. (13), 294.

${ }^{18}$ Evangelical Magazine, op. cit. (13), 495.

${ }^{19}$ [Wilberforce], op. cit. (13), 165-6.

${ }^{20} 15$ th edition in 1815 , followed by a spate of editions in $1817-18$ as the work came out of copyright. A. Fyfe, work in progress.

${ }^{21}$ Paley, op. cit. (5), 63.

${ }^{22}$ C. Bell to G.J. Bell (1835), in G. J. Bell, Letters of Sir Charles Bell, London, 1870, 339-40.

${ }^{23}$ LeMahieu, op. cit. (11), 79.

${ }^{24}$ J. H. Brooke, 'Natural theology and the plurality of worlds,' Annals of Science (1977), 34, 221-86; J.

R. Topham, “'An Infinite Variety of Arguments": The Bridgewater Treatises and British Natural 
Theology in the 1830s,' PhD thesis, Lancaster University, 1993, Ch. 4.

${ }^{25}$ Darwin to Lubbock, 1859, in Darwin, op. cit. (1) ii, 219.

${ }^{26} C U C, 1802$, xii.

27، Alpha Beta', 'An Account of Cambridge,' The Monthly Magazine (1803), 15, 27.

${ }^{28}$ C. Wordsworth, Scholae Academicae [1877], London, 1968, v.

${ }^{29}$ The reforms are discussed in D. A. Winstanley, Early Victorian Cambridge, Cambridge, 1955; and Wordsworth, op. cit. (28).

${ }^{30}$ I have examined the memoirs, biographies, or letters of the following: Charles Astor Bristed, Edward Daniel Clarke, Charles Darwin, Henry Gunning, John Stevens Henslow, Joseph Romilly, Adam Sedgwick, Charles Simeon, William Whewell, and J. M. F. Wright.

${ }^{31}$ J. H. Brooke, Science and Religion, Cambridge, 1991, Ch. 6.

${ }^{32}$ [Wilberforce], op. cit. (13), 162.

${ }^{33}$ For an account of the examination system, see $C U C, 1802$, introduction. Wordsworth, op. cit. (28), 33, repeats the account and reports that it is based upon J. Jebb, Works, 1772.

${ }^{34}$ Wordsworth, op. cit. (28), 52.

${ }^{35}$ H. Sidgwick, 'Philosophy at Cambridge', Mind (1876), 1, 239.

${ }^{36}$ Gascoigne, Cambridge in the Age of Enlightenment, Cambridge, 1989, 264.

${ }^{37}$ CUC, $1828,161$.

${ }^{38}$ CUEP, CUL.

${ }^{39} C U C, 1802, \mathrm{xxxix}$.

${ }^{40} \mathrm{BA}$ examination, March, 1830, CUEP, 1830.

${ }^{41}$ January 17th, 1831, CUEP, 1831.

${ }^{42}$ Gascoigne, op. cit. (36), 238.

${ }^{43}$ Gascoigne, op. cit. (36), 251-6.

${ }^{44}$ A.W. Brown, Recollections of the Conversation Parties of the Reverend Charles Simeon (1863), 326, quoted in Gascoigne, op. cit. (36), 262.

${ }^{45} C U C, 1802,38-41$.

${ }^{46}$ E.g. Thomas Martyn, the botany professor from 1761-1826 had not lectured for thirty years (despite still having his lectures listed in $C U C$ ) when Henslow took over. See CUC, 1825-26, and L. Jenyns, 
(post Blomefield), Memoir of the Rev. John Stevens Henslow, London, 1862, 37.

${ }^{47}$ Becher, op. cit. (4), 60 .

${ }^{48}$ Jenyns, op. cit. (46), 27-8.

${ }^{49}$ See the registers for Henslow's botanical lectures, 1828-33, CUL archives. I am grateful to Max Walters for bringing these to my attention. W. Phillips, An elementary introduction to the knowledge of mineralogy, 1816 and/or An outline of mineralogy and geology, 1815, as well as E. D. Clarke, A Syllabus of lectures in mineralogy, 1807, (reprinted 1818) and The gas blow-pipe, 1819 frequently appeared on booksellers bills. See bills from J \& J Deighton and Sons, and Nicholson \& Sons, Lady Day 1820. Dr. French's Pupils' Bills, Private Papers of Dr. W. French, box I, Jesus College Archives, Cambridge [JCA].

${ }^{50}$ Henslow's registers, op. cit. (49)

${ }^{51} \mathrm{~W}$. Buckland, Vindiciae Geologicae; or the Connexion of Geology with religion explained, Oxford, 1820.

${ }^{52}$ Paley, op. cit. (5), Ch. 7, esp. 61-2.

${ }^{53}$ E.g. W. Prout, Chemistry, Meteorology and the Function of Digestion considered with reference to natural theology, (Bridgewater Treatise), 1834.

${ }^{54}$ Paley, op. cit. (5), Ch. 22.

${ }^{55}$ E.g. W. Whewell, Astronomy and General Physics considered with reference to natural theology, (Bridgewater Treatise), 1833. Astronomy had also been a popular topic for natural theologies before Paley, e.g. W. Derham, Astro-Theology, 1715.

${ }^{56}$ 'The being of God demonstrated in the works of creation,' 'Unity of God,' 'The goodness of God proved from the light of nature and revelation,' 'The ills of life do not contradict the goodness of God.' Reprinted in E. Paley (ed.), op. cit. (6), 405-52.

${ }^{57}$ E.g. W. Buckland, Geology and mineralogy considered with reference to natural theology (Bridgewater Treatise), 1836, i, vii-viii, quoted in Topham, op. cit. (24), 110.

${ }^{58}$ A. Sedgwick, op. cit. (7), 88. He also suggested that Whewell's Bridgewater might fit very well with 'the course of reading of our best class of students.'

${ }^{59}$ A. Sedgwick, op. cit. (7), 19.

${ }^{60}$ Whewell to Rose, 1826. I. Todhunter, William Whewell DD, London, 1876, 78. 
${ }^{61}$ Jenyns, op. cit. (46), 177, quotes Henslow's 1846 appeal to members of the University on behalf of a new Botanic Garden.

${ }^{62}$ Buckland, op. cit. (51), 28.

${ }^{63}$ Sedgwick, op. cit. (7), 15, 16.

${ }^{64}$ Jenyns, op. cit. (46), 176, 2-3.

${ }^{65 ، A l p h a ~ B e t a ', ~ o p . ~ c i t . ~(27), ~ 28, ~ f n ; ~[J . ~ M . ~ F . ~ W r i g h t], ~ A l m a ~ M a t e r ; ~ o r, ~ S e v e n ~ Y e a r s ~ a t ~ t h e ~ U n i v e r s i t y ~ o f ~}$ Cambridge, London, 1827, 222; CUC, 1802, 31. By 1829, this requirement had been reduced to twenty lectures, CUC, 1829, 37.

${ }^{66}$ J. B. Hollingworth, Heads of Lectures in Divinity, Cambridge, 1825, $2^{\text {nd }}$ edn $1831,3^{\text {rd }}$ edn 1835.

${ }^{67}$ Hollingworth, op. cit. (66), $1^{\text {st }}$ edn, 2.

${ }^{68}$ Hollingworth, op. cit. (66), $1^{\text {st }}$ edn, lectures 44-5.

${ }^{69}$ LeMahieu, op. cit. (11), 59.

${ }^{70}$ W. Whewell, English University Education, 1837, 55. Quoted in Garland, op. cit. (2), 121.

${ }^{71}$ Mrs. S. Douglas, William Whewell, DD, 2nd edn, London, 1882, 9-10.

${ }^{72}$ e.g. a prize was established at St. John's College in 1765 'for the commencing BA, who having gained mathematical honours should distinguish himself by knowledge of Moral Philosophy', Wordsworth, op. cit. (28), 122.

${ }^{73}$ This total excludes the recently established Downing College.

${ }^{74}$ Ordered by the Master and Seniors, June 9th 1819. Notebook of Thomas Jephson, SJA.

${ }^{75}$ Examination results, May 30th 1820, Notebook of Thomas Jephson, SJA.

${ }^{76}$ H.A. Woodham to W. French, 5th December [184-]. Private Papers of Dr. W. French, box II, JCA.

${ }^{77}$ CUEP (Colleges), CUL.

${ }^{78}$ Examination Books 1766-1843, SJA.

${ }^{79}$ C. A. Bristed, Five Years in an English University, New York, 1852, 139.

${ }^{80}$ 'Questions on the Course of Theological Lectures, King's College, Easter Term 1832,' in CUEP (Colleges), CUL. 